\title{
Evaluation of Strength and Durability Properties for Various Amount of Bacillus Subtilis Bacteria in Concrete
}

\author{
Abishek Kumar A. A \\ Assistant Professor, \\ Department of Civil Engineering, \\ Adi Shankara Institute of Engineering and Technology, \\ Ernakulam, India
}

\begin{abstract}
Concrete is one of the predominantly used material in the construction industry. It is important to reduce problems on concrete are disintegration, erosion, etc. One such drawback that concerns the construction industry is that the concrete tends to crack when subjected to tension. This then promotes seepage of water causing corrosion of steel reinforcement making the whole structure vulnerable. MICP process by the bacillus subtilis bacteria is considered to avoid this kind of failure that adversely affects the strength and durability of structures. As the grain to grain calcite precipitation in the concrete during the MICP process improves the bond strength between the cement particles. This paper discusses the experimental study conducted to evaluate the compressive, flexural, and split tensile strength of bacteria concrete as well as the durability properties like water absorption and acid attack resistance of bacteria concrete with various amounts of Bacillus subtilis.
\end{abstract}

Keywords-Bacteria concrete; MICP Process; Bacillus Subtilis; strength; durability

\section{INTRODUCTION}

Concrete is a versatile construction material, utilized in a wide selection of situations. Cracks in concrete occur due to distinct techniques such as shrinkage, freeze-thaw reaction, and mechanical compressive and low tensile strength. With improper treatment, cracks tend to expand further and eventually require expensive repair. The durability of concrete is also diminished by these cracks since it paves an easy path for the transportation of liquids and gases that potentially harmful substances. If micro-cracks grow and reach the reinforcement, not only the concrete itself is attacked but also the reinforcement may corrode when it is exposed to the environment. However, the cracks formed within the concrete are due to a lack of strength and durability. The Microbiologically Enhanced Cracks Remediation (MECR) method promotes calcium carbonate (calcite) precipitation. In this technique, Urolytic bacteria are used hence the concrete is called Bacterial concrete, which can be prepared by adding spore-forming bacteria in the concrete that are able to perpetually precipitate calcite, and this process is called Microbiologically Induced Calcite Precipitation (MICP). MICP process by the bacillus subtilis bacteria induced calcium carbonate deposition has been proposed as an alternative and environmental friendly crack repair technique to avoid this kind of failure that adversely affects the strength and durability of structures. This process is an outcome of

\author{
Eveena Stephen ${ }^{1}$, Merin George ${ }^{2}$, \\ Ansaf muhammad ${ }^{3}$, Naveen Charles ${ }^{4}$ \\ Student ${ }^{1,2,3,4}$, \\ Department of Civil Engineering, \\ Adi Shankara Institute of Engineering and Technology, \\ Ernakulam, India
}

metabolic interactions between microbial communities with organic and/or inorganic compounds present in the concrete. Thus MICP has been an aid in the development of bioconcrete and improvement in the strength and durability properties of concrete at the various amounts of Bacillus subtilis in the specimen.

\section{A. Objectives}

The following are the objectives of the experimental study:

- To check and compare the strength properties of Bio Concrete with conventional concrete in terms of compression, tension and flexure.

- To check the durability parameters of Bio Concrete.

\section{MATERIALS AND TEST RESUlts}

The following are the materials used for making concrete as per IS 10262: 2019 guidelines:

\begin{tabular}{|l|l|}
\hline \multicolumn{1}{|c|}{ Table I. Materials used in concrete } \\
\hline Materials & \multicolumn{1}{c|}{ Specifications } \\
\hline Cement & $\begin{array}{l}\text { Portland Pozzolana cement conforming to IS } \\
1489 \text { (part1) }\end{array}$ \\
\hline Fine aggregate & $\begin{array}{l}\text { Natural river sand passing through 4.75mm } \\
\text { sieve conforming to grading Zone II of Table 9 } \\
\text { of IS 383 }\end{array}$ \\
\hline Coarse aggregate & $\begin{array}{l}\text { Crushed angular aggregate of maximum } \\
\text { nominal size 20mm conforming to Table 7 of } \\
\text { IS 383 }\end{array}$ \\
\hline Water & $\begin{array}{l}\text { Locally available portable water confirming to } \\
\text { standards specified in IS: 456-2000 }\end{array}$ \\
\hline Chemical admixture & $\begin{array}{l}\text { Super plasticizer, water reducing admixture } \\
\text { conforming to IS 9103 }\end{array}$ \\
\hline Bacteria & Bacillus subtilis \\
\hline
\end{tabular}

\section{A. Effect of portland pozzolana cement}

Portland pozzolana cement produces less heat of hydration and offers greater resistance to the attack of aggressive water than normal Portland cement. It reduces the leaching of lime liberated during the setting and hydration of cement. This is particularly useful in hydraulic construction and other mass concrete structures. The roller bearing shape of ash significantly aids the workability of concrete. This permits lower sand content than conventional mixes while handling remains similar. As the proportion of sand is reduced, all capability aspects of the concrete are enhanced. The fly ash in spherical particle shape, less water is required to attain the identical level of the slump. 


\section{B. Bacillus subtilis}

Bacillus subtilis is a bacteria used in bio-concrete. This is a spore-forming, motile, rod-shaped, Gram-positive, facultative aerobe. It is predominantly found in soil and vegetation with an optimal growth temperature from 25-35 degrees Celsius. This is also familiar by the names Bacillus uniflagellatus, Bacillus globigii, and Bacillus natto. Bacillus has evolved with strategies to survive under harsh conditions.

The following are the results of tests conducted on materials:

\begin{tabular}{|l|l|l|}
\hline \multicolumn{2}{|c}{ Table II. Material test results } \\
\hline \multicolumn{1}{|c|}{ Materials } & \multicolumn{1}{|c|}{ Material tests } & \multicolumn{1}{c|}{ Test results } \\
\hline \multirow{2}{*}{ Cement } & $\begin{array}{l}\text { Standard consistency } \\
\text { test as per IS: 4031 (Part } \\
\text { 4) }\end{array}$ & $28 \%$ \\
\hline & $\begin{array}{l}\text { Initial setting time as } \\
\text { per IS 4031, IS 269 }\end{array}$ & 31 min \\
\hline & $\begin{array}{l}\text { Specific gravity as per } \\
\text { IS 2720- Part 3 }\end{array}$ & 2.88 \\
\hline Fine aggregate & $\begin{array}{l}\text { Specific gravity as per } \\
\text { IS: 2386(Part -III)-1963 }\end{array}$ & 2.65 \\
\hline & $\begin{array}{l}\text { Water absorption as per } \\
\text { IS: 2386(Part -III)-1963 }\end{array}$ & $1 \%$ \\
\hline & $\begin{array}{l}\text { Sieve analysis as per IS: } \\
\text { 2386(Part -I)-1963 }\end{array}$ & $\begin{array}{l}\text { Conforming II of Table 7 of IS } \\
\text { grading }\end{array}$ \\
\hline $\begin{array}{l}\text { Coarse } \\
\text { aggregate }\end{array}$ & $\begin{array}{l}\text { Specific gravity as per } \\
\text { IS: 2386(Part -III)-1963 }\end{array}$ & 2.74 \\
\hline & $\begin{array}{l}\text { Water absorption as per } \\
\text { IS: 2386(Part -III)-1963 }\end{array}$ & $0.5 \%$ \\
\hline & $\begin{array}{l}\text { Sieve analysis as per IS: } \\
\text { 2386(Part -I)-1963 }\end{array}$ & $\begin{array}{l}\text { Conforming to Table 7 of } \\
\text { IS 383 }\end{array}$ \\
\hline
\end{tabular}

\section{C. slump test}

The concrete slump test of fresh concrete as per IS: 11991959 is used to measure the workability of concrete. The slump test is essentially a measure of the consistency of fresh concrete or its workability. Once the concrete abates the difference in height to the original height of the slump cone is measured as the slump. Therefore the initial and final slump height is found to be 30 and $22.5 \mathrm{~cm}$, thus the slump value is determined to be $7.5 \mathrm{~cm}$

\section{MIX DESIGN AND CASTING OF SPECIMEN}

As per IS 10262: 2019 guidelines, the M40 mix was used. The mixed proportion obtained was 1: 1.53: 2.93: 0.4: 0.01, which stands for cement, fine aggregate, coarse aggregate, water and chemical admixture. Bacterial concrete was cast using PPC mixed with different bacterial concentrations $(5 \mathrm{ml}$, $10 \mathrm{ml}$, and $15 \mathrm{ml}$ ), also conventional concrete samples were cast in parallel.

\section{A. Working principle}

The bacterial concrete mix was prepared using Bacillus subtilis along with nutrients from which the bacteria could potentially produce calcite. The bacteria genus Bacillus has been found to thrive in the high-alkaline environment of concrete due to its extremely thick outer cell membrane that enables them to remain viable until a suitable environment is available to grow. The healing agent can be applied in concrete by the method of direct application. The application of a healing agent by the direct method was used for finding the optimum concentration of bacteria for strength purposes. Thus improving the grain to grain bond with the help of calcite precipitated by the bacteria as a result of a biochemical reaction called MICP process. Also as soon as the crack ruptures, the healing agent is released into the crack faces by capillary movement thus enhancing the durability of the concrete. Thereby the healing agent also associates with the safeguard and closure of the near-by cracks.

\section{B. Preparation of samples}

The concrete samples were prepared for both bacteria ( in $5 \mathrm{ml}, 10 \mathrm{ml}, 15 \mathrm{ml}$ ) and normal mixes according to the IS: 10262-2019. Different shapes and sizes of moulds are prepared for evaluating the strength and durability characteristics of concrete. Cubical specimens of size $150 \mathrm{x}$ $150 \times 150 \mathrm{~mm}$ are cast for compressive strength test and water absorption test, cylindrical specimens of size $150 \times 300$ $\mathrm{mm}$ are prepared for split tensile strength test, and Beam specimens of size $100 \times 100 \times 500 \mathrm{~mm}$ are cast for flexural strength test and acid attack test. The moulds are fixed tightly and coated with oil and concrete is poured in three layers of each mould. The healing agent was applied to the concrete by the direct application method where the bacteria is added while tamping in the concrete which helps in the distribution of bacteria. The tamping was done with a rod of the rounded end for 25 times, which distributed concrete and bacteria equally in the mould. The specimens are demoulded after 24hrs and cured for 7, 14 and 28 days. The three specimens of each are taken as an average for evaluating the test results.

\section{RESULTS OF STRENGTH AND DURABILITY TESTS ON HARDENED CONCRETE}

\section{A. Compressive strength}

Cubes of size $15 \mathrm{~cm} \times 15 \mathrm{~cm} \times 15 \mathrm{~cm}$ (IS: 10086-1982) were casted. All the specimens were provided with adequate time for hardening and cured for 7, 14 and 28 days. After the enumerated period ( 7,14 and 28 days) all the specimens were examined for its maximum load in the compression testing machine. The compressive strength of concrete for specimens with different bacterial concentrations at 7 days, 14 days and 28 days is given in Fig 1. It was observed that the compressive strength of bacteria concrete showed a serious increase than conventional concrete. The maximum increase in strength of bacterial concrete compared to conventional concrete at 7 days, 14 days and 28 days are $4.8 \%$ for $10 \mathrm{ml}$, $12.21 \%$ for $10 \mathrm{ml}$ and $1.33 \%$ for $10 \mathrm{ml}$. There was an improvement in compressive strength for every $10 \mathrm{ml}$ bacterial mix samples when compared to any other.

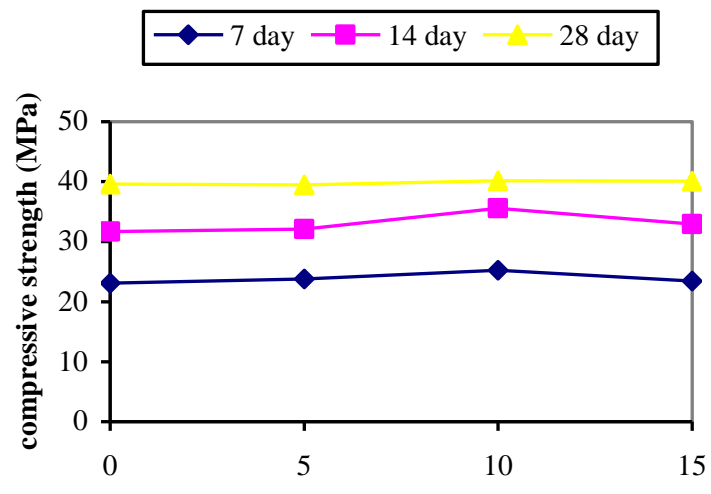

Amount of bacteria (ml)

Fig 1.7day, 14day and 28day compressive strength comparison 


\section{B. Split tensile strength}

The split tensile strength of concrete specimens with different bacterial concentrations at 7 days, 14 days and 28 days is given in the Fig 2. Cylinders of size $150 \mathrm{~mm} \times 300 \mathrm{~mm}$ were cast. After 24 hours, the specimens were demoulded and undertook for water curing. The 7, 14 and 28 days cured cylinders were taken, allowed to dry and tested in the compressive testing machine by placing the specimen horizontal.

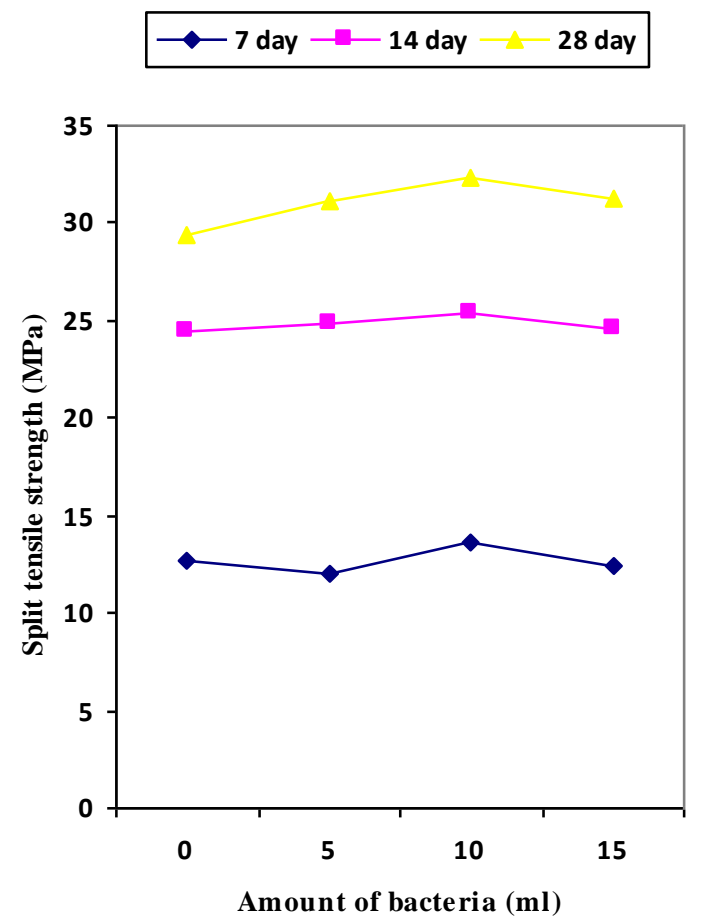

Fig 2. 7day, 14day and 28day split tensile strength comparison

It was observed that with the addition of bacteria, there is a significant increase in the tensile strength. The maximum increase in strength of bacterial concrete compared to conventional concrete at 7 day, 14 day and 28 day are $7 \%$ for $10 \mathrm{ml}, 4.21 \%$ for $10 \mathrm{ml}$ and $10 \%$ for $10 \mathrm{ml}$. There was an improvement in split tensile strength for every $10 \mathrm{ml}$ bacterial mix samples when compared to any other.

\section{Flexural strength}

The flexural Strength on standard beam specimens with different bacterial concentrations at 7 days, 14 days and 28 days is given in the Fig 3. After 24 hours, the specimens were demoulded and undertook to water curing. The 7, 14 and 28 days cured cylinders were taken, allowed to dry and tested in flexural strength testing machine.

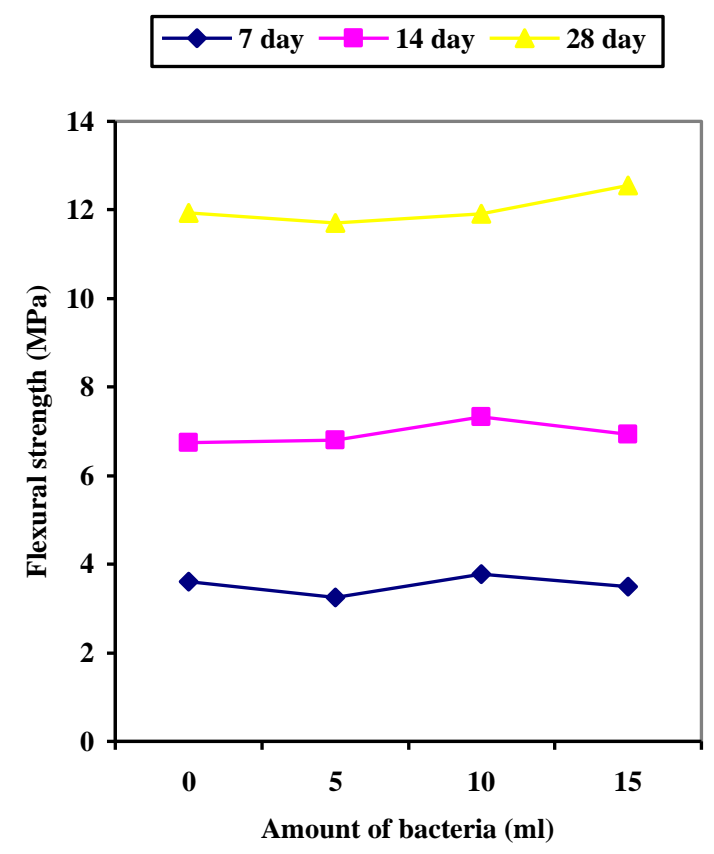

Fig 3. 7day, 14day and 28day split tensile strength comparison

It was observed that with the addition of bacteria, there is a significant increase in the tensile strength. The maximum increase in strength of bacterial concrete compared to conventional concrete at 7 days, 14 days and 28 days are $4.72 \%$ for $10 \mathrm{ml}, 12.44 \%$ for $10 \mathrm{ml}$ and $5.2 \%$ for $15 \mathrm{ml}$. There was an improvement in split tensile strength for bacterial mix samples of $10 \mathrm{ml}$ at 7 days and 14 days, also $15 \mathrm{ml}$ at 28 days when compared to any other.

D. Water absorption

Cubes of size $15 \mathrm{~cm}$ x $15 \mathrm{~cm}$ x $15 \mathrm{~cm}$ (IS: $10086-1982)$ were casted. All the specimens were provided with adequate time for hardening and cured for 7, 14 and 28 days. After the enumerated period $(7,14$ and 28 days) all the specimens then underwent the water absorption test. The increase in weight for each sample is shown in the Fig 5. A lower rate of water absorption was obtained for bacterial concrete compared to conventional concrete. The maximum increase in weight was $0 \mathrm{ml}$ specimen and the minimum increase in weight was for $10 \mathrm{ml}$ bacteria. A $9.72 \%$ decrease in water absorption was noted for $10 \mathrm{ml}$ when compared to $0 \mathrm{ml}$ specimen, this is because of the microorganisms actuated development of calcium carbonate in the voids in concrete, directing to a lesser void and hence a lesser permeability. 


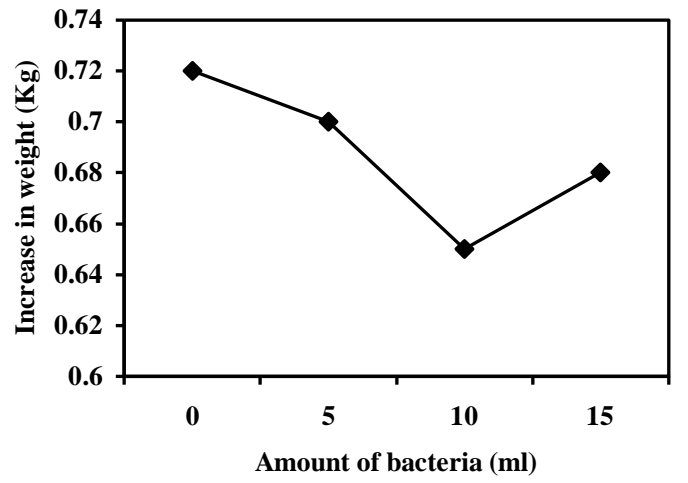

Fig 5. Water absorption test result comparison of the different bacterial concentrations

\section{E. Acid Attack}

Acid attack is the dissolution and leaching of acidsusceptible components, mainly calcium hydroxide from the cement paste of hardened concrete. This action results in an increase in capillary porosity, loss of cohesiveness and eventually loss of strength. The following Fig 6. shows the loss of weight in specimens of different bacterial concentrations.

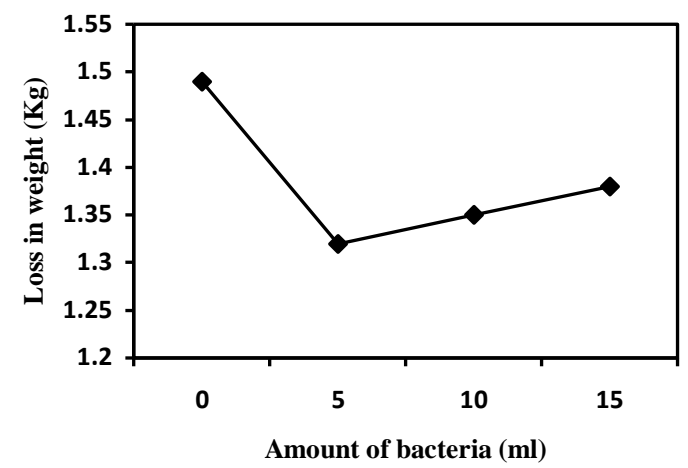

Fig 6. Acid attack result comparison of the different bacterial concentrations

It was evaluated that the calcite precipitated by bacteria which filled the micro-cracks, increasing the nonporous nature of the concrete. This resulted in the loss of weight of bacteria concrete samples at $5 \mathrm{ml}$ to a minimum of $11.40 \%$ when compared to conventional concrete samples.

\section{CONCLUSION}

The following conclusions arrive from the conducted experimental study and the results are indicated as follows.

- The use of bacteria in concrete proves to be more effective with an increase in strength and durability. This depends on the amount of calcite produced and how effective these precipitate in gluing particles together. It also manifests that healing property is more and is effectively increasing the risk of failure.

- Bacterial concrete with a concentration of bacteria of $10 \mathrm{ml}$ was found to give the best results out of the samples used. Hence it could be concluded that this particular concentration gives optimum results which are proven by an increase in compressive strength, split tensile strength and a decrease in water absorption when compared to conventional concrete.

- The increase in strength of microbial concrete is mainly due to the filling of the pores and voids with microbiologically induced calcium carbonate precipitation. Thus bacterial concrete is less vulnerable.

- Addition of bacterial causes a reduction in water absorption and acid attack which could in turn increase the durability of concrete structures. The reducing water absorption was because of the effectiveness of bacteria in depositing layers of calcium carbonate into the cavities, pores and micro-cracks of concrete specimens that seal pores and micro-cracks.

- The study accomplishes that the use of bacteria (Bacillus Subtilis) in concrete enhances its strength and durability mainly due to the plugging of the pores inside the concrete specimens due to microbiologically induced calcium carbonate precipitation.

\section{REFERENCES}

[1] Meera C. M. and Dr. Subha V, "strength and durability assesment of bacteria based self-healing concrete," IOSR Journal of mechanical and civil engineering, e-ISSN:2278-1684, P-issn:2320-334X, January 2016.

[2] Mohit Goyal and P. Krishna Chaitanya, "Behaviour of Bacterial Concrete as Self-Healing Material," International Journal of Emerging Technology and Advanced Engineering, ISSN 2250-2459, ISO 9001:2008 Certified Journal, Volume 5, Issue 1, January 2015.

[3] V. Nagarajan, T. Karthik Prabhu, M. Gowri Shankar and P. Jagadesh, "A Study on the Strength of the Bacterial Concrete Embedded with Bacillus Megaterium," International Research Journal of Engineering and Technology (IRJET), e-ISSN: 2395-0056, Volume: 04, Issue: 12, Dec-2017, www.irjet.net, p-ISSN: 2395-0072.

[4] S .Vijaya Bhaskar Reddy and Ankathi. Ravikiran, "Experimental Studies on Mechanical Properties of Bacterial Concrete with Fly Ash," International Journal of Applied Engineering Research ISSN 09734562 Volume 13, Number 15 (2018), pp. 11857-11870 (C) Research India Publications ,http://www.ripublication.com

[5] Jasira Bashir, Ifrah Kathwari, Aditya Tiwary and Khushpreet Singh "Bio Concrete- The Self-Healing Concrete, Indian Journal of Science and Technology," Vol 9(47), DOI: 10.17485/ijst/2016/v9i47/105252, December 2016.

[6] J. Rex ,J. Selwyn Babu and S. Pooja Sri Reddy, "Strength and durability aspects of bacteria concrete," International journal of innovative technology and exploring engineering(IJITEE) ISSN: 22783075, volume-8, Issue-252, December.

[7] E. Ezhilarasi, G. Geeta and K. Baskaran, "Experimental study on flexural behavior of self-healing concrete using bacillus substilis bacteria," International Journal of Engineering Research and technology (IJERT) ISSN:2278-0181 Vol 5 Issue 12, December 2016.

[8] Shubham Ajay Puranik, Siddharth Jain, G. Sritam and Sayali Sandbhor "Bacterial Concrete- A Sustainable Solution for Concrete Maintenance," (IJITEE) ISSN: 2278-3075, Volume-8, Issue-11S, September 2019. 